\title{
Fifteen Reasons I Don't Want To Work
}

\author{
Harriet Ellenberger
}

Avec son habituelle lucidité et dans le style parfois décapant qui caractérise une partie de son oeuvre, Harriet Ellenberger expose ici ses raisons de refuser les conditions du travail tel qu'il se pratique à travers les institutions contemporaines.

1. I don't have time.

2. Everything else is more interesting.

3. Women do two-thirds of the world's work - most of it unpaid — and look where it's gotten us.

4. There must be a better way to survive.

5. Jobs are ruinous to the art of conversation.

6. To harness one's creative power to someone else's goals is a form of slavery.

7. The work world worships the clock, but the clock takes no account of the natural rhythms of the body and the universe.

8. In the modern world that defines work, nothing has value until it passes through the marketplace. Nonetheless, it remains true that the best things in life are free.

9. The workplace is soul-less.

10. Computer screens give me a headache.

11. Children aren't allowed in offices. 
12. People tend to identify their Self with their job - a syndrome leading inevitably to boredom.

13. When you work in an office or school or store or factory or fast food restaurant, you forget that life is an adventure.

14. The work world is unkind to poets.

15. I hate to be bossed. 